\title{
First Job Waiting Times after College Graduation Based on the Graduates Occupational Mobility Survey in Korea
}

\author{
Sungim Lee ${ }^{1} \cdot$ Jeounghoon Moon ${ }^{2}$ \\ ${ }^{1}$ Department of Statistics, Dankook University \\ ${ }^{2}$ Department of Statistics, Dankook University
}

(Received March 13, 2012; Revised April 10, 2012; Accepted November 12, 2012)

\begin{abstract}
Each year research institutions such as the Korea Employment Information Service(KEIS), a government institution established for the advancement of employment support services, and Job Korea, a popular Korean job website, announce first job waiting times after college graduation. This provides useful information understand and resolve youth unemployment problems. However, previous reports deal with the time as a completely observed one and are not appropriate. This paper proposes a new study on first job waiting times after college graduation set to 4 months prior to graduation. In Korea, most college students hunt for jobs before college graduation in addition, the full-fledged job markets also open before graduation. In this case the exact waiting time of college graduates can be right-censored. We apply a Cox proportional hazards model to evaluate the associations between first job waiting times and risk factors. A real example is based on the 2008 Graduates Occupational Mobility Survey(GOMS).
\end{abstract}

Keywords: The time to get first job after graduation of college, variable selection, Cox's Proportional Hazard model, survival analysis.

\section{1. 서론}

청년실업문제는 등록금 문제와 더불어 최근 대학가의 가장 큰 이슈이며, 사회 전반에 걸쳐 큰 문제가 되 고 있다. 청년실업문제는 대학 이상의 고등교육을 받은 인재들이 사회에서 효율적으로 운영되지 않는 다는 점에서 대졸자 당사자들만의 문제가 아닌 사회적으로도 중요한 문제이다. 그런데 청년실업문제의 배경인 청년실업률에 대한 체감률은 여러 조사기관에서 발표하는 취업률과 상당한 차이가 있는 것을 볼 수 있다. 이것은 취업률을 산정하는 방법에서 취업에 대한 정의가 일반 청년들이 생각하는 취업과 다르 기 때문이다. 마찬가지로 여러 조사기관에서는 대학 졸업 후 첫 일자리를 얻는 데까지 걸리는 기간을 산 정하여 발표하고 있는데, 이 역시 조사기관에 따라 다른 산정 기준으로 인해 차이가 있었다. 이처럼 조 사기관마다 서로 다른 발표 결과는 우리 사회의 중요한 문제를 정확하게 인식하지 못하는 문제를 가져 오게 된다. 2008 년 5 월 통계청에서는 청소년의 졸업·중퇴자 중 $90.7 \%$ 가 취업경험이 있으며, 첫 일자리

${ }^{1}$ Corresponding author: Professor, Department of Statistics, Dankook University, 152, Jukjeon-ro, Suji-gu, Yongin-si, Gyeonggi-do 448-701, Korea. E-mail: silee@dankook.ac.kr 
Table 1.1. Comparison of subjects and definition of employment for computing the waiting time to get first job according to research organizations.

\begin{tabular}{llll}
\hline & \multicolumn{1}{c}{ Subjects } & $\begin{array}{c}\text { Definition } \\
\text { of employment }\end{array}$ & Note \\
\hline Statistics Korea & $15-19$ years old & $\begin{array}{l}\text { work over an hour } \\
\text { for a week }\end{array}$ & $\begin{array}{l}\text { If a person gets a job before graduation, } \\
\text { the waiting time is defined as one month. }\end{array}$ \\
\hline KEIS & college graduates & $\begin{array}{l}\text { work over an hour } \\
\text { for a week }\end{array}$ & $\begin{array}{l}\text { If a person gets a job before graduation, } \\
\text { the waiting time is defined as zero. }\end{array}$ \\
\hline Job Korea, Inc. & $\begin{array}{l}\text { employee as } \\
\text { college graduates }\end{array}$ & $\begin{array}{l}\text { work as a } \\
\text { permanent position }\end{array}$ & \\
\hline
\end{tabular}

를 구하는 데까지는 11 개월이 걸린다고 발표했다. 취업포털 사이트인 잡코리아에서는 대상자를 달리하 여 2008년 4년제 대졸 정규직 취업자 1,025 명을 대상으로 첫 구직기간을 조사한 결과, 평균 11.2 개월 이 걸린다고 발표했다. 또한 한국고용정보원의 2008년 대졸자 직업이동 경로조사에서는 2-3년제 대학 교 졸업자의 첫 구직기간이 수도권의 대졸자는 3.1 개월, 비수도권의 대졸자는 2.6 개월이라고 하였으며, 4 년제 대학교 졸업자의 경우 수도권의 대졸자는 6.5 개월, 비수도권의 대졸자는 6.1 개월이라고 발표했다. 이는 앞서 언급한 통계청 발표의 첫 구직기간보다 5 개월 이상 짧은 수치이다. 이처럼 각 기관에서 발표 하는 첫 구직기간은 서로 차이가 있으며, 조사대상 또한 서로 다른 것을 알 수 있다.

각 조사기관의 산정기준을 정리하면 Table 1.1 과 같다. 여기서 살펴보면 조사기관에서 발표하는 첫 구 직기간이 다른 몇 가지 이유를 짐작해 볼 수 있다.

첫째, 조사기관에 따라 조사대상이 서로 다른 것을 볼 수 있다. 통계청의 '경제활동인구 부가조사'의 경 우 고등학교와 대학교를 구분하지 않고 15-29세를 대상으로 졸업 또는 중퇴 이후 첫 취업까지 걸리는 기간을 분석하였는데, 이는 고졸자와 대학중퇴자는 물론 사이버대학, 기술대학 등의 대졸자도 모두 포함 된다는 문제가 있다. 반면 한국고용정보원은 대졸자만을 대상으로 첫 구직기간을 발표하였는데, 여기에 는 직장생활을 하면서 대학에 다닌 사람들인 고연령의 대졸자가 상당수 포함이 되어 있다. 이들의 경우 첫 구직기간은 포함되지 않기 때문에 첫 구직기간이 과소추정 될 개연성이 존재한다는 문제가 생긴다. 하지만 이보다 더 큰 문제점은 첫 구직기간 산정 시 조사시점에서 취업에 성공한 사람만을 대상으로 한 다는 것이다. 때문에 미취업자를 고려하지 않은 첫 구직기간이 실제의 첫 구직기간보다 더 짧게 나타나 는 것은 당연한 결과이다. 둘째, 조사기관의 취업에 대한 정의와 일반적으로 생각하는 취업의 차이이다. 통계청과 한국고용정보원에서의 취업자에 대한 정의는 지난 1 주간 수입을 목적으로 1 시간 이상 근로한 자와 가족기업을 위해 주당 18 시간 이상을 근로한 자를 말한다. 여기에는 청년들 중 취업을 하지 못해 일시적인 아르바이트를 하는 경우에도 취업자로 분류된다는 문제가 있다. 이러한 취업의 정의는 일반적 으로 생각하는 취업의 정의와는 차이가 있는데, 최근 잡코리아 등 기타 조사기관에서는 취업의 정의를 정규직으로 한정하여 발표하고 있다. 셋째, 대학 졸업 전에 취업한 학생들의 첫 구직기간 산정법의 차이 이다. 통계청에서는 졸업 이전 취업을 한 경우 입직 소요기간을 1 개월로 산정하고 있지만, 한국고용정 보원에서는 이를 0 개월로 산정한다.

이렇듯 조사기관에 따라 다른 산정기준으로 인해 첫 일자리를 구하는 데까지 걸리는 기간이 다르게 발 표되고 있다. 본 논문에서는 대졸자를 대상으로 대학 졸업 후 첫 일자리를 구하는 데까지 걸리는 기간 을 첫 구직기간으로 정의하고, 이를 연구하는 데 있어 대졸자의 취업이라는 사회현상을 좀 더 잘 반영할 수 있도록 연구대상자와 첫 구직기간 정의를 새롭게 정하고자 한다. 우선 2절에서는 첫 구직기간에 대 한 연구대상자를 새롭게 선정하고, 3 절에서는 이를 바탕으로 첫 구직기간과 그 구직기간에 미치는 요인 들에 관하여 알아보고자 한다. 마지막으로 4절에서는 결론 및 향후과제에 대하여 다루겠다. 


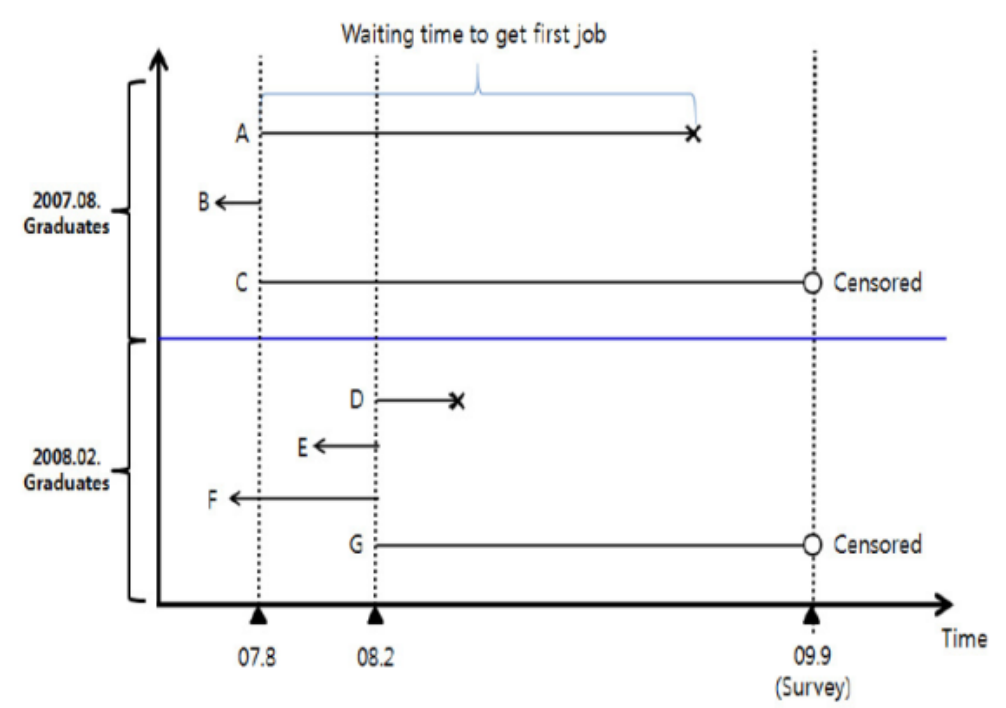

Figure 2.1. The waiting time to get first job acquiring in '2008 GOMS' data.

\section{2. 첫 구직기간에 대한 새로운 산정법}

\section{1. 첫 구직기간 정의}

본 연구에서 사용하는 자료는 노동부와 한국고용정보원에서 국내 대졸자를 대상으로 매년 조사되는 패널 자료인 '대졸자 직업이동 경로조사(Graduates Occupational Mobility Survey; GOMS)'이다. GOMS는 국내최대의 대졸자 단기(3년) 패널 조사로써 2-3년제 대학 이상의 대졸자를 대상으로 매년 진행되며, 본 연구에서 사용할 $2008 \mathrm{GOMS1}$ 자료는 2007년 8월과 2008년 2월에 졸업한 2-3년제 이상 대졸자(약 50 만명) 중 약 $4 \%$ 인 18,066 명으로 구성되어 있으며, 설문조사는 이들이 졸업한 지 23 개월에 서 29 개월이 지난 2009 년 9 월에 실시되었었다. 이때 취업자에 대한 정의는 정부의 발표와 마찬가지로 지난 1 주일간 수입을 목적으로 1 시간 이상 근로한 사람으로 하였다. 또한 GOMS에서는 직장생활을 하 면서 대학에 다닌 고령자들 또한 포함하고 있어, 본 연구에서는 조사당시 연령이 20살부터 30 살까지의 청년으로 분석대상자를 제한하였다. 이러한 연령제한은 실제 사회문제가 되고 있는 청년 대졸자의 첫 구직기간을 추정하는데 바람직할 것이다.

먼저 Figure 2.1에서 살펴볼 수 있듯이 2009년 9월 조사시점을 기준으로 청년 대졸자들은 구직을 한 경 우와 구직을 하지 못한 경우로 나눠진다. Figure 2.1 의 A, B, C는 2007년 8월 졸업자를 나타내며, D, $\mathrm{E}, \mathrm{F}, \mathrm{G}$ 는 2008 년 2 월 졸업자를 나타낸다. $\mathrm{A}$ 와 $\mathrm{D}$ 는 대학 졸업 후 조사시점 전 구직에 성공한 경우로 졸업시점을 기준시점으로 한다면 첫 구직기간은 졸업 후 첫 일자리를 구한 기간으로 계산되며 $\mathrm{C}$ 와 $\mathrm{G}$ 는 조사시점까지 구직에 성공하지 못한 경우이다. 그런데 졸업시점을 기준시점으로 할 경우의 문제는 $\mathrm{B}$, $\mathrm{E}$, 그리고 $\mathrm{F}$ 의 첫 구직기간 산정 시 발생하게 된다. 이러한 경우에 통계청은 졸업이전 취업의 경우는 모두 첫 구직기간을 1 개월로, 한국 고용정보원은 0 개월로 산정한다.

Figure 2.1과 같이 조사시점에 중도절단 자료를 포함하는 구직기간을 확률변수 $Y_{i}$ 로 나타내면 다음과 같이 정의된다:

$$
Y_{i}=T_{i} \wedge C_{i}, \quad \delta_{i}=I\left(T_{i} \leq C_{i}\right) .
$$


Table 2.1. Frequency distribution table based about first employed within 23-29 months after college graduate.

\begin{tabular}{ccc}
\hline Whether employed or not employed & Frequency (\%) \\
\hline Not employed & $1,521(13.35)$ \\
employed & $9,871 \quad(86.65)$ \\
\hline Total & $11,392(100.00)$ \\
\hline
\end{tabular}

이때, $T_{i}$ 는 $i$ 번째 대졸자가 취업에 성공할 때까지 걸린 시간을 나타내며, $C_{i}$ 는 중도절단 시간을 나타낸 다. 이때, $\delta_{i}$ 는 $i$ 번째 대졸자의 취업여부를 나타내며, 취업을 한 경우는 1 , 취업이 안 된 경우는 0 을 나 타낸다.

본 논문에서는 청년 대졸자가 첫 취업까지의 기간을 산정하기 위한 기준시점을 우리나라 고용의 특성을 고려해 새롭게 정의하고자 한다. 일반적으로 우리나라에서 제일 많은 고용을 창출하는 대기업의 공채 시기는 학생들의 졸업 전에 있게 된다. 즉 취업시점이 졸업시점보다 우선한다는 것인데, 이런 경우 졸 업을 기준시점으로 하여 첫 구직시까지를 첫 구직기간으로 정의할 경우에 문제가 발생하게 된다. 우리 나라 기업의 공채는 크게 상반기 공채와 하반기 공채로 구분된다. 그 중 상반기 공채는 대개 $4-5$ 월, 하 반기 공채는 대개 10-11월에 취업이 확정된다. 다시 말해 졸업이 8월인 학생들은 대개 약 4개월 전인 4-5월, 졸업이 2 월인 학생들은 약 4 개월 전인 10-11월이 취업이 확정되는 시기인 것이다. 이에 본 논 문에서는 첫 구직기간을 산정하기 위해 졸업연월로부터 4 개월 전 시점을 기준시점으로 산정하였다. 즉 졸업과 동시에 취업한다는 것은 공채시기로부터 4 개월이 늦었다고 판단하여 첫 구직기간이 0 개월이 아 니라 4 개월로 정의하였다. 우리나라의 취업특성을 고려하여 졸업연월 4 개월 전에 취업한 경우는 대학과 정을 수료하고 취업한 경우로 간주하기 어렵다고 가정하여 분석대상에서 제외하였다. 이는 GOMS자료 중 $8.63 \%$ 으로 나타났으며, 공채 6 개월 전부터 취업을 하는 것으로 나타났다. 이것은 졸업 10 개월 전부 터 취업이 시작된 것을 의미한다. 실제로 졸업 전 취업이 확정된 사람들의 비율이 대학생 당사자들이 느 끼는 취업률이므로 이런 측면에서 기준시점에 대한 새로운 정의는 의미가 있다고 할 수 있다.

\section{2. 대학 졸업 후 첫 구직기간의 분포}

2.1절에서 정의한 것처럼 분석 대상자를 한정하고 첫 구직기간에 대한 정의를 새롭게 하여 첫 구직기간 에 대한 분포를 추정하고자 한다. Table 2.1은 졸업 후 첫 구직 여부를 중심으로 나누어진 관측값의 빈 도표이다. 대학을 졸업하고 약 2 년이 지난 시점에서 대졸자의 $86.65 \%$ 가 취업에 성공했음을 알 수 있다.

첫 구직기간에 대하여 Kaplan과 Meier (1958)의 생존함수 추정량을 사용한 결과는 Figure 2.2 와 같다. 이때 구직기간 $(T)$ 는 졸업년월 4 개월 전을 기준시점(0개월)으로 하여 첫 직장을 잡을때까의 시간을 나 타낸다. 생존함수의 추정값 $\hat{P}(T>t)$ 은 첫 구직까지 $t$ 개월 이상이 소요될 확률을 나타낸다. Figure 2.2 를 살펴보면 대학 졸업 4 개월 전에 취업한 경우는 전체 대상자의 $2.48 \%$ 인 것으로 나타났으며, 그 후 1 년간 취업이 꾸준하게 이루어지는 것을 볼 수 있다. 그러나 첫 구직까지 1 년 이상이 걸리는 대졸자도 전체의 $20 \%$ 가 넘는 것을 알 수 있다.

좀 더 자세히 살펴보면 첫 구직기간이 4 개월 이상인 경우는 $69 \%$ 로 나타났으며, 이것은 졸업 시 취업이 확정되는 경우가 대졸자의 $31 \%$ 라는 것을 의미한다. 즉 10 명 중 약 3 명만이 졸업 전에 첫 일자리가 확 정된다는 것이다. 또한, 첫 구직기간이 6 개월(졸업 후 2 개월)이상일 확률이 $51 \%$ 라는 것은 졸업 후 2 개 월이 지난시점에도 대졸자의 $49 \%$ 가 취업하지 못했음을 나타낸다. 이것은 대학생들의 취업난이 매우 심 각하다는 것을 말해준다. 다음 절에서는 이러한 첫 구직기간이 다른 여러 요인과 어떠한 연관성이 있는 지 분석해보도록 한다. 
(Unit : Months)

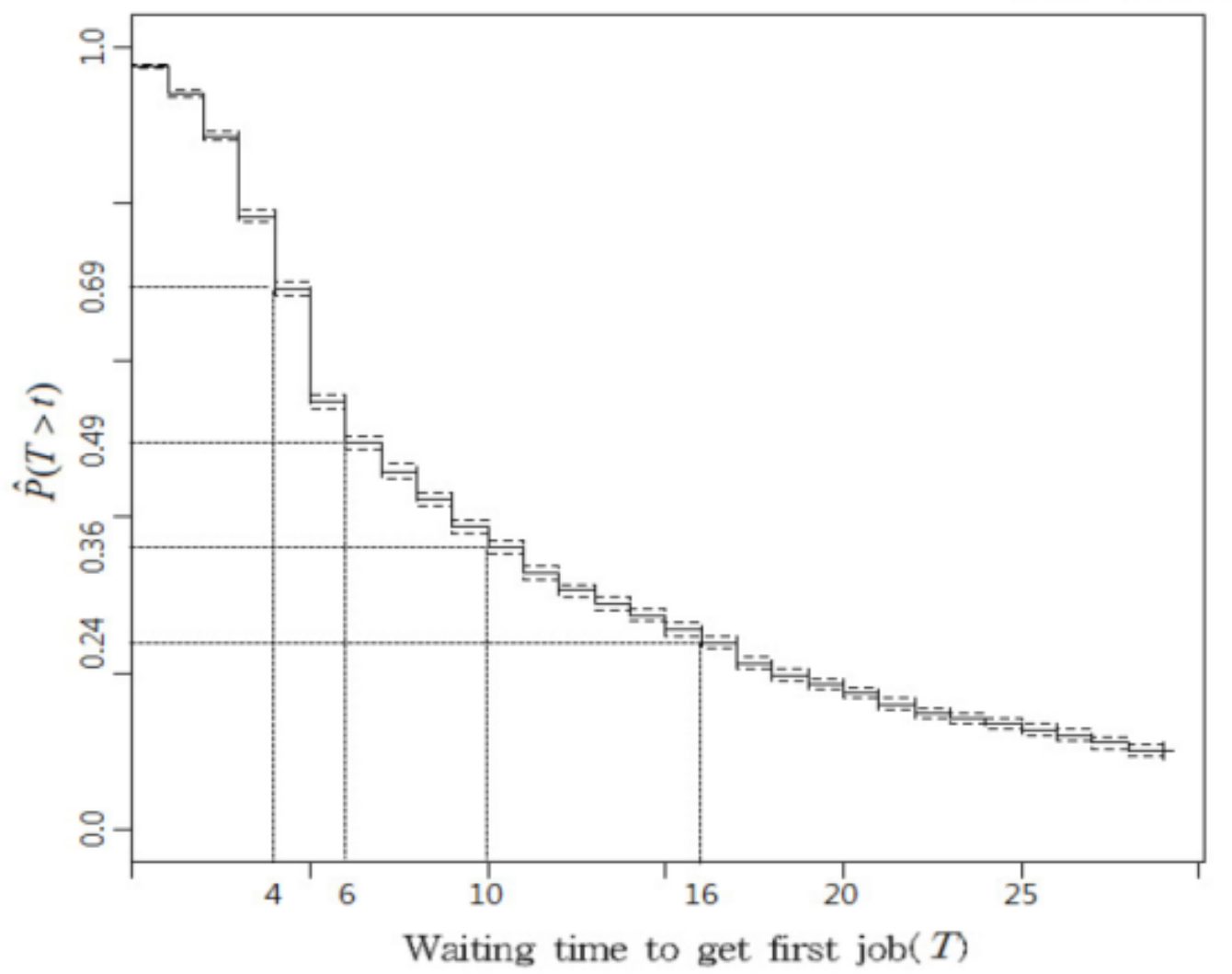

Figure 2.2. Survival function of the waiting time $(T)$ to get first job

\section{3. 분석}

2.3.1. 변수의 설정 취업에 있어서 인구학적 요인과 학력 요인은 매우 큰 영향을 준다. GOMS 자 료로부터 첫 구직기간에 영향을 주는 요인을 Table 2.2 와 같이 세 가지로 분류하였다.

먼저 인구학적 요인으로는 성별(남자의 경우 군 복무 경험 고려), 나이, 거주지, 혼인상태, 부모님과의 동거 여부, 본인 가구주 여부, 가족규모, 출생지역, 부모님 학력, 대학입학 당시의 부모님 소득 등이 포 함되며, 학교생활 관련 요인으로는 전공, 학교유형, 학교 소재지, 입학과 편입의 구분, 복수·부.연계전공 여부, 졸업 평점, 영어 시험 점수, 영어 외 외국어 점수 취득 여부, 휴학경험 여부 등이 포함된다. 마지 막으로 구직활동에 관련된 요인으로는 재학 중 인턴 경험 여부, 어학연수 경험 여부, 취업 목표 유무, 일 자리 탐색 경험 여부, 직업 훈련 및 교육 경험 여부, 자격증 소지 유무, 전문 시험 준비 경험 여부 등이 포함된다.

2.3.2. 첫 구직기간에 대한 인구학적 요인의 영향 Table 2.3 은 대졸자의 인구학적 변수가 졸업 후 첫 구직기간에 미치는 영향을 $\mathrm{Cox}$ 의 비례위험모형 (Cox, 1972)을 이용하여 변수를 하나씩만 적용한 결 과이다. 
Table 2.2. Potential variables related to the waiting time to get first job.

\begin{tabular}{l|l|l}
\hline \multicolumn{1}{c|}{ Demographic } & \multicolumn{1}{|c}{ College life } & \multicolumn{1}{|c}{ Job-seeking behaviour } \\
\hline Gender & Major & Internship experience \\
Age & Type of School & Study abroad experience \\
Residence & College location & Employment goals \\
Marital status & Admission/Transfer & Job searching experience \\
Householder & Not a single major & Job training experience \\
Living with parents & GPA & Certification \\
Family size & English level & Specialist preparation \\
Region of birth & Second language level & \\
Father's education & Leave of absence experience & \\
Mother's education & & \\
Parents income during college entrance & & \\
\hline
\end{tabular}

인구학적 요인 중 첫 구직기간에 대하여 유의수준 $5 \%$ 에서 통계적으로 유의하다고 나타난 변수는 성별, 나이, 거주지역, 혼인상태, 부모님과의 동거 여부, 본인이 가구주 여부, 가족규모, 아버지 학력과 어머니 학력 등이다. 먼저 성별만을 독립변수로 사용할 경우 여자와 군대를 다녀오지 않은 남자의 첫 구직기간 이 유의한 차이가 있었다. 대졸자의 $50 \%$ 가 취업하는 기간을 살펴보면 군필의 남자가 6 개월로 가장 짧 았으며, 다음으로는 여자의 첫 구직기간이 7 개월, 미필의 남자가 9 개월로 가장 늦은 것을 알 수 있었다. 다음으로 나이와 관련하여 20 대 초반의 대졸자가 20 대 중·후반의 대졸자들보다 첫 구직기간이 더 짧은 것으로 나타났다. 또한, 가족의 부양 의무가 있는 기혼의 대졸자와 본인이 가구주인 대졸자가 그렇지 않 은 대졸자에 비해 첫 구직기간이 짧은 것으로 나타났다. 반면 부모님과 동거를 하는 대졸자의 경우가 그 렇지 않은 경우보다 첫 구직기간이 더 긴 것으로 나타났는데, 이것은 최근 대학을 졸업했지만 변변한 일 자리를 찾지 못해 부모에게 용돈을 받으며 살고 있다는 '니트족'이 최근 경제난과 맞물려 급증하고 있다 는 것에 대한 반증으로 보인다. 가족규모 면에서는 소가족에 속하는 대졸자가 대가족에 속하는 대졸자 에 비해 첫 구직기간이 더 짧은 것으로 나타났다.

2.3.3. 학교생활 요인에 따른 첫 구직기간 분포 Table 2.4 는 대졸자의 학교생활 변수가 첫 구직기간에 미치는 영향을 Cox의 비례위험모델을 이용하여 위와 같은 방법으로 시행한 결과이다.

학교생활 요인 중 첫 구직기간에 대하여 유의수준 0.05 하에서 통계적으로 유의하다고 나타난 변수는 전 공, 학교유형, 졸업평점, 영어성적, 영어 외 외국어 점수 유무, 휴학 경험 등이다. 먼저 전공만을 독립변 수로 사용할 경우 인문계열 전공자에 비해 사회계열, 공학계열, 의약계열, 예체능계열 전공자의 첫 구직 기간이 더 짧으며, 반면 교육계열과 자연계열의 전공자는 인문계열의 전공자에 비해 첫 구직기간이 더 긴 것으로 나타났다. 대졸자의 $25 \%$ 가 취업하는 기간이 가장 짧은 전공계열은 공학계열로써 3 개월로 나 타났으며, 반면 교육계열은 5 개월로 가장 늦게 취업하는 것으로 나타났다. 또한, 대졸자의 $50 \%$ 가 취 업하는 기간이 가장 짧은 전공계열은 의약계열로써 5 개월이며, 인문계열과 자연계열의 전공자들이 8 개 월로 나타났다. 즉, 기간별로 전공계열에 따라서 첫 구직기간이 다르다는 것을 알 수 있었다. 다음으 로 학교유형과 관련하여 전문대 대졸자가 4년제 졸업생과 교육대 졸업생에 비해 첫 구직기간이 더 짧으 며, 전문대와 교육대 졸업생의 경우에는 졸업자의 $50 \%$ 가 취업하는 기간이 4 년제보다 2 개월 정도 빨랐 다. 또한, 영어성적은 설문에 응답하지 않은 대졸자의 첫 구직기간이 가장 짧은 것으로 나타났으나, 응 답하지 않는 대졸자가 전체의 $63.66 \%$ 의 비율을 차지하기 때문에 이들의 분포를 볼 필요가 있다. 다음의 Table 2.5 는 영어성적 응답여부와 취업한 대졸자들의 기업에서 종사하는 사원수를 비교해본 결과이다. 두 변수의 독립성 검정결과 유의확률이 0.000 이하로 두 변수가 독립이 아니라고 할 수 있으며, 대체적 
Table 2.3. Demographic factor affect the period.

\begin{tabular}{|c|c|c|c|c|c|c|c|c|}
\hline Variable & Level & Frequency(\%) & \multicolumn{5}{|c|}{$\begin{array}{l}\text { The first period of employment } \\
\text { of } p \% \text { college graduates: } \hat{t}_{p}^{\dagger}\end{array}$} & $e^{\bar{\beta}}(p \text {-value })^{\ddagger}$ \\
\hline \multirow{3}{*}{ Gender*** } & Female & $4.804(42.17)$ & 4 & 7 & 13 & 18 & 27 & \\
\hline & $\begin{array}{c}\text { Male: Military } \\
\text { service obligation }\end{array}$ & $6,273(55.06)$ & 3 & 6 & 12 & 18 & $>29$ & $1.03(0.212)$ \\
\hline & Others & $315 \quad(2.77)$ & 5 & 9 & 18 & $>29$ & $>29$ & $0.73(0.000)^{* * *}$ \\
\hline \multirow{3}{*}{$\mathrm{Age}^{* * *}$} & Early $20 \mathrm{~s}$ & $1,359(11.93)$ & 4 & 5 & 11 & 17 & 26 & \\
\hline & Mid 20s & $7,309(64.16)$ & 4 & 7 & 14 & 19 & $>29$ & $0.86(0.000)^{* * *}$ \\
\hline & Late $20 \mathrm{~s}$ & $2,724(23.91)$ & 3 & 6 & 12 & 18 & $>29$ & $0.90(0.004)^{* *}$ \\
\hline \multirow{2}{*}{ Residence** $^{* *}$} & Others & $5,078(44.58)$ & 4 & 7 & 14 & 19 & $>29$ & \multirow[b]{2}{*}{$1.07(0.001)^{* *}$} \\
\hline & Metropolitan area & $6,314(55.42)$ & 4 & 6 & 12 & 18 & 28 & \\
\hline Marital & No & $10,900(95.68)$ & 4 & 7 & 13 & 19 & $>29$ & \\
\hline Status*** & Yes & $492 \quad(4.32)$ & 3 & 5 & 8 & 12 & 25 & $1.34(0.000)^{* * *}$ \\
\hline \multirow{2}{*}{$\begin{array}{l}\text { Householder } \\
\text { Status*** }\end{array}$} & Others & $8,044(70.61)$ & 4 & 7 & 15 & 21 & $>29$ & \multirow[b]{2}{*}{$1.43(0.000)^{* * *}$} \\
\hline & Householder & $3,348(29.39)$ & 3 & 5 & 10 & 13 & 20 & \\
\hline \multirow{2}{*}{$\begin{array}{l}\text { Living with } \\
\text { parents*** }\end{array}$} & No & $4,393(38.56)$ & 4 & 6 & 11 & 17 & 28 & \multirow[b]{2}{*}{$0.90(0.000)^{* * *}$} \\
\hline & Yes & $6,999(61.44)$ & 4 & 7 & 14 & 19 & $>29$ & \\
\hline \multirow{2}{*}{$\begin{array}{l}\text { Family } \\
\text { size*** }\end{array}$} & Small & $10,126(88.89)$ & 4 & 6 & 12 & 18 & 28 & \multirow[b]{2}{*}{$0.87(0.000)^{* * *}$} \\
\hline & Large & $1,266(11.11)$ & 4 & 7 & 16 & 21 & $>29$ & \\
\hline \multirow{2}{*}{$\begin{array}{l}\text { Region of } \\
\text { birth }\end{array}$} & Others & $6,738(59.15)$ & 4 & 6 & 13 & 18 & $>29$ & \multirow[b]{2}{*}{$1.02(0.267)$} \\
\hline & Metropolitan & $4,654(40.85)$ & 4 & 6 & 12 & 19 & 28 & \\
\hline \multirow{3}{*}{$\begin{array}{l}\text { Father's } \\
\text { education*** }\end{array}$} & Less than a high school & $2,674(23.47)$ & 4 & 6 & 12 & 17 & 26 & \multirow{3}{*}{$\begin{array}{l}0.96(0.129) \\
0.90(0.001)^{* * *}\end{array}$} \\
\hline & High school & $5,128(45.01)$ & 4 & 6 & 13 & 18 & 28 & \\
\hline & More than a college & $3,590(31.51)$ & 4 & 6 & 14 & 20 & $>29$ & \\
\hline \multirow{3}{*}{$\begin{array}{l}\text { Mother's } \\
\text { education*** }\end{array}$} & Less than a high school & $3,792(33.29)$ & 4 & 6 & 12 & 18 & 27 & \multirow{3}{*}{$\begin{array}{l}0.97(0.189) \\
0.88(0.000)^{* * *}\end{array}$} \\
\hline & High school & $5,794(50.86)$ & 4 & 6 & 13 & 18 & $>29$ & \\
\hline & More than a college & $1,806(15.85)$ & 4 & 7 & 15 & 22 & $>29$ & \\
\hline \multirow{3}{*}{$\begin{array}{l}\text { Parents income } \\
\text { during } \\
\text { college entrance }\end{array}$} & Low & $2,008(17.63)$ & 4 & 6 & 12 & 18 & $>29$ & \multirow{3}{*}{$\begin{array}{l}0.99(0.659) \\
0.98(0.523)\end{array}$} \\
\hline & Middle & $7,312(64.19)$ & 4 & 6 & 13 & 18 & 28 & \\
\hline & High & $2,072(18.19)$ & 4 & 6 & 13 & 19 & $>29$ & \\
\hline
\end{tabular}

$\hat{t_{p}}$ : The first period of employment of \% college graduates, unit : month

$\dagger: p \%$ of college graduates success in first employ up to $\hat{t}_{p}$ months by using Estimation of Kaplan-Meier

$\ddagger$ : $P$-value of each variable is estimated by Cox's proportional hazard model.

으로 영어성적에 응답한 대졸 취업자들의 기업의 규모가 더 크다는 것을 알 수 있었다. 하지만 대졸자의 $50 \%$ 가 첫 구직기간이 가장 빠른 그룹은 역시 상위권의 대졸자이며 그 외의 그룹보다 2 개월이나 빠른 것 을 알 수 있었다.

2.3.4. 구직활동 요인에 따른 첫 구직기간 분포 Table 2.6 은 대졸자의 구직 활동 변수가 졸업 후 첫 구직기간에 미치는 영향을 $\mathrm{Cox}$ 의 비례위험모델을 이용하여 위와 같은 방법으로 시행한 결과이다.

구직 활동 요인은 첫 구직기간에 대하여 모든 변수가 유의수준 0.05 하에서 통계적으로 유의하다고 나타 났다. 대부분 취업과 관련하여 준비를 해왔던 대학생들의 첫 구직기간이 짧은 것으로 나타났는데, 일자 리 탐색 경험이 있거나 직업 훈련 및 교육 경험이 있는 대졸자들이 이러한 경험이 없는 대졸자에 비해 대졸자의 $50 \%$ 가 취업하는 기간이 1 개월 이상 짧은 것을 알 수 있었다. 다음으로 전문 시험 준비를 하는 
Table 2.4. College life factor affect the period.

\begin{tabular}{|c|c|c|c|c|c|c|c|c|}
\hline Variable & Level & Frequency $(\%)$ & \multicolumn{5}{|c|}{$\begin{array}{l}\text { The first period of employment } \\
\text { of p\% college graduates : } \hat{t}_{p}^{\dagger} \\
\hat{t}_{25} \hat{t}_{50} \hat{t}_{70} \hat{t}_{80} \hat{t}_{90}\end{array}$} & $e^{\bar{\beta}}(p \text {-value })^{\ddagger}$ \\
\hline \multirow{7}{*}{ Major*** } & Liberal arts & $1,297(11.39)$ & 4 & 8 & 14 & 20 & $>29$ & \\
\hline & Social sciences & $2,282(20.03)$ & 4 & 7 & 14 & 20 & $>29$ & $1.04(0.249)$ \\
\hline & Education & $979 \quad(8.59)$ & 5 & 7 & 16 & 18 & 27 & $0.99(0.881)$ \\
\hline & Engineering & $3,283(28.82)$ & 3 & 6 & 12 & 17 & 28 & $1.15(0.000)^{* * *}$ \\
\hline & Science & $1,672(14.68)$ & 4 & 8 & 16 & 24 & $>29$ & $0.91(0.016)^{*}$ \\
\hline & Medicine & $675 \quad(5.93)$ & 4 & 5 & 7 & 10 & 17 & $1.49(0.000)^{* * *}$ \\
\hline & $\begin{array}{c}\text { Arts and } \\
\text { physical education }\end{array}$ & $1,204(10.57)$ & 4 & 6 & 12 & 17 & 24 & $1.17(0.000)^{* * *}$ \\
\hline \multirow{3}{*}{$\begin{array}{l}\text { Type of } \\
\text { school*** }^{*}\end{array}$} & University & $8,594(75.44)$ & 4 & 7 & 14 & 20 & $>29$ & \multirow{3}{*}{$\begin{array}{l}1.25(0.000)^{* * *} \\
1.18(0.008)^{* *}\end{array}$} \\
\hline & College & $2,520(22.12)$ & 4 & 5 & 10 & 15 & 22 & \\
\hline & Teacher's College & $278 \quad(2.44)$ & 5 & 5 & 11 & 17 & 17 & \\
\hline College & Others & $6,356(55.79)$ & 4 & 7 & 13 & 18 & 28 & \\
\hline location & Metropolitan area & $5,036(44.21)$ & 4 & 6 & 12 & 19 & $>29$ & $1.01(0.470)$ \\
\hline Admission & Special type & $323(2.84)$ & 4 & 8 & 14 & 20 & 26 & \\
\hline Transfer & Regular type & $11,069(97.16)$ & 4 & 6 & 13 & 18 & $>29$ & $1.02(0.744)$ \\
\hline \multirow{2}{*}{$\begin{array}{l}\text { Multiple } \\
\text { major }\end{array}$} & No & $9,174(80.53)$ & 4 & 6 & 13 & 18 & $>29$ & \multirow[b]{2}{*}{$0.99(0.626)$} \\
\hline & Yes & $2,218(19.47)$ & 4 & 7 & 13 & 18 & 28 & \\
\hline \multirow{3}{*}{$\mathrm{GPA}^{* *}$} & Low & $4,693(41.20)$ & 4 & 7 & 14 & 19 & $>29$ & \multirow{3}{*}{$\begin{array}{l}1.06(0.006)^{* *} \\
1.08(0.009)^{* *}\end{array}$} \\
\hline & Middle & $4,846(42.54)$ & 4 & 6 & 12 & 18 & 28 & \\
\hline & High & $1,853(16.27)$ & 4 & 5 & 12 & 18 & $>29$ & \\
\hline \multirow{4}{*}{$\begin{array}{l}\text { English } \\
\text { level*** }^{* * *}\end{array}$} & NA & $7,252(63.66)$ & 4 & 6 & 11 & 17 & 27 & \multirow{4}{*}{$\begin{array}{l}0.83(0.089) \\
0.78(0.000)^{* * *} \\
0.87(0.000)^{* * *}\end{array}$} \\
\hline & Low & $93 \quad(0.82)$ & 5 & 9 & 14 & 20 & $>29$ & \\
\hline & Middle & $2,176(19.10)$ & 5 & 9 & 16 & 22 & $>29$ & \\
\hline & High & $1,871(16.42)$ & 3 & 7 & 14 & 21 & $>29$ & \\
\hline Second & No & $10,801(94.81)$ & 4 & 6 & 13 & 18 & 28 & \multirow[b]{2}{*}{$0.89(0.014)^{*}$} \\
\hline language* & Yes & $591 \quad(5.19)$ & 4 & 8 & 16 & 20 & $>29$ & \\
\hline \multirow{2}{*}{$\begin{array}{l}\text { Leave of absence } \\
\text { experience }{ }^{* * *}\end{array}$} & No & $2,781(24.41)$ & 4 & 6 & 11 & 17 & 26 & \multirow[b]{2}{*}{$0.92(0.000)^{* * *}$} \\
\hline & Yes & $8,611(75.59)$ & 4 & 7 & 13 & 19 & $>29$ & \\
\hline
\end{tabular}

$\hat{t_{p}}$ : The first period of employment of $\%$ college graduates, unit : month

Table 2.5. Cross table of non-respondents/respondents for the question of English level according to the number of employees engaged in organizations.

\begin{tabular}{l|ccc}
\hline & Non-respondents $(\%)$ & Respondents $(\%)$ \\
\hline Less than 100 persons & $3,529 \quad(55.0)$ & $1,206 \quad(35.0)$ \\
100-999 persons & $1,396 \quad(21.7)$ & $871 \quad(25.2)$ \\
More than 1,000 persons & $1,494 \quad(23.3)$ & $1,375 \quad(39.8)$ \\
\hline Total & $6,419(100.0)$ & $3,452(100.0)$ \\
\hline
\end{tabular}

대졸자는 전문 시험 준비를 하지 않은 대졸자보다 첫 구직기간이 더 긴 것을 알 수 있었다. 이러한 전문 시험에는 공무원 또는 공단(사), 교원임용 시험 또는 회계사, 법무사 등의 전문자격시험이나 언론사 시 험이 속하며, 이러한 대졸자들은 대졸 직후 당장 취업의 뜻을 두지 않고 전문 시험을 치른 후 취업을 하 기 때문이라고 볼 수 있겠다. 
Table 2.6. Job-seeking factor affect the period.

\begin{tabular}{|c|c|c|c|c|c|c|c|c|}
\hline Variable & Level & Frequency $(\%)$ & $\begin{array}{c}\text { The } \\
\text { of } p \% \\
\hat{t}_{25}\end{array}$ & $\begin{array}{l}\text { t pe } \\
\text { olleg } \\
\hat{t}_{50} \\
\end{array}$ & $\begin{array}{l}\text { of } \\
\text { aduc } \\
\hat{t}_{70} \\
\end{array}$ & $\begin{array}{l}\text { loymer } \\
: \hat{t}_{p}^{\dagger} \\
\hat{t}_{80}\end{array}$ & $\hat{t}_{90}$ & $e^{\bar{\beta}}(p \text {-value })^{\ddagger}$ \\
\hline \multirow{2}{*}{$\begin{array}{l}\text { Internship } \\
\text { experience }\end{array}$} & No & $10,236(89.85)$ & 4 & 7 & 13 & 19 & $>29$ & \multirow[b]{2}{*}{$1.16(0.000)^{* * *}$} \\
\hline & Yes & $1,156(10.15)$ & 3 & 5 & 11 & 17 & 25 & \\
\hline \multirow{2}{*}{$\begin{array}{l}\text { Study abroad } \\
\text { experience** }\end{array}$} & No & $9,222(80.95)$ & 4 & 6 & 13 & 19 & $>29$ & \multirow[b]{2}{*}{$1.07(0.008)^{* *}$} \\
\hline & Yes & $2,170(19.05)$ & 3 & 6 & 12 & 17 & 28 & \\
\hline \multirow{2}{*}{$\begin{array}{l}\text { Employment } \\
\text { goals*** }\end{array}$} & No & $3,856(33.85)$ & 4 & 7 & 15 & 21 & $>29$ & \multirow[b]{2}{*}{$1.16(0.000)^{* * *}$} \\
\hline & Yes & $7,536(66.15)$ & 4 & 6 & 12 & 17 & 27 & \\
\hline \multirow{2}{*}{$\begin{array}{l}\text { Job searching } \\
\text { experience }{ }^{* * *}\end{array}$} & No & $4,042(35.48)$ & 4 & 8 & 20 & $>29$ & $>29$ & \multirow[b]{2}{*}{$1.68(0.000)^{* * *}$} \\
\hline & Yes & $7,350(64.52)$ & 4 & 6 & 11 & 15 & 21 & \\
\hline \multirow{2}{*}{$\begin{array}{l}\text { Job training } \\
\text { experience }^{* * *}\end{array}$} & No & $8,839(77.59)$ & 4 & 7 & 14 & 20 & $>29$ & \multirow[b]{2}{*}{$1.27(0.000)^{* * *}$} \\
\hline & Yes & $2,553(22.41)$ & 3 & 5 & 11 & 15 & 21 & \\
\hline \multirow{2}{*}{ Certification $^{* * *}$} & No & $3,179(27.91)$ & 4 & 7 & 14 & 21 & $>29$ & \multirow[b]{2}{*}{$1.10(0.000)^{* * *}$} \\
\hline & Yes & $8,213(72.09)$ & 4 & 6 & 12 & 18 & 27 & \\
\hline \multirow{2}{*}{$\begin{array}{l}\text { Specialist } \\
\text { preparation*** }\end{array}$} & $\mathrm{No}$ & $8,532(74.89)$ & 4 & 6 & 11 & 16 & 26 & \multirow[b]{2}{*}{$0.66(0.000)^{* * *}$} \\
\hline & Yes & $2,860(25.11)$ & 5 & 11 & 18 & 25 & $>29$ & \\
\hline
\end{tabular}

$\hat{t_{p}}$ : The first period of employment of \% college graduates, unit : month

$\dagger$ : $p \%$ of college graduates success in first employ up to $\hat{t}_{p}$ months by using Estimation of Kaplan-Meier

$\ddagger$ : $P$-value of each variable is estimated by Cox's proportional hazard model.

\section{3. 자료 분석}

\subsection{Cox의 비례위험모형(Cox's Proportional Hazard Model)}

첫 구직기간 $(T)$ 에 영향을 주는 여러 독립변수의 효과를 고려하기 위해 $\operatorname{Cox}(1972,1975)$ 가 제안한 Cox의 비례위험모형을 사용하였다. 본 연구에서는 GOMS1 자료로부터 얻은 Table 2.2 의 변수들을 이 용하여 첫 구직기간에 영향을 미치는 요인을 살펴보았다. 대졸자의 첫 구직기간에 영향을 미치는 독립 변수의 개수를 $p$ 라 하고 $\operatorname{Cox}$ 의 비례위험모형을 다음과 같이 정의하였다:

$$
\begin{aligned}
h_{i}(t) & =h_{0}(t) \exp \left(\beta^{\prime} x_{i}\right) \\
& =h_{0}(t) \exp \left(\beta_{1} x_{i 1}+\beta_{2} x_{i 2}+\cdots+\beta_{2} x_{i p}\right) .
\end{aligned}
$$

이때, 독립변수 $x_{i}^{\prime}=\left(x_{i 1}, x_{i 2}, \ldots, x_{i p}\right)$ 는 $i$ 번째 대졸자의 특성을 나타내며, $\beta=\left(\beta_{1}, \beta_{2}, \ldots, \beta_{p}\right)$ 는 회귀 계수, 그리고 $h_{0}(t)$ 는 기저위험함수(baseline hazard function)를 나타낸다.

\section{2. 모형의 선택}

모든 변수를 사용하여 모형을 적합할 경우, 자기상관성이 존재하거나 추정된 계수가 유의하지 않을 수 도 있으며, 계수의 부호 또한 반대로 추정될 수도 있다 (Frisch, 1934; Achen, 1982). 그러므로 $p$ 개의 설명변수들로부터 적절한 변수를 선택하는 것은 중요한 문제이다. $p$ 개의 변수를 모형에 적합할 시 가능 한 모든 모형의 수는 총 $2^{p}$ 개로 모형선택의 어려움을 가져온다. 예를 들어 10 개의 변수가 존재할 경우 의 가능한 모든 모형의 수인 $2^{10}$ 개, 즉 1,024 개의 모형을 고려해야 하며 변수가 34 개일 경우에는 가능한 모형의 수인 $2^{34}$ 개, 즉 약 170 억 개의 모형을 고려해야 하는 데, 이를 직접 비교하는 일은 매우 비현실적 이다. 
이러한 모형 중에서 최적모형을 선택하는 자동화된 모형의 선택방법으로는 전진선택법(forward selection method), 후진소거법(backward elimination method), 단계적 선택법(stepwise selection method)과 최적 변수 선택법(the best subsets selection method) 등이 있다. 이러한 변수선택법들 은 모형에 적합 되는 변수를 감소시키는 효과를 가져다준다. 또한, 자동화된 모형의 선택방법 외의 정 보기준(information criterion)을 이용한 모형선택 방법 또한 널리 이용된다. Akaike (1973, 1974)의 Akaike Information Criterion(AIC)와 Schwarz (1978)의 Bayesian Information Criterion(BIC)를 이 용하여 가장 적합한 모형을 찾는 과정을 갖는다. 이때 $\mathrm{AIC}$ 와 $\mathrm{BIC}$ 의 공식은 다음과 같다.

$$
\begin{aligned}
& \mathrm{AIC}=-2 \log \left(L_{n}(\hat{\beta})\right)+2 p, \\
& \mathrm{BIC}=-2 \log \left(L_{n}(\hat{\beta})\right)+\log \left(\sum \delta_{j}\right) .
\end{aligned}
$$

이때, $\mathrm{BIC}$ 에서의 $\delta_{j}$ 는 $j$ 번째 관측값의 사건 발생 여부로써 본 연구에서는 첫 구직 여부를 나타낸 것 이다 (Volinsky와 Raftery, 2000). 위 두 식의 첫 번째 항은 모형적합 정도의 척도이며 첫 번째 항의 $L_{n}(\hat{\beta})$ 는 편우도함수로서 다음과 같이 정의된다:

$$
L_{n}(\hat{\beta})=\Pi_{i=1}^{n}\left(\frac{\exp \left(x_{i}^{\prime} \beta\right)}{\sum_{j \in R_{i}} \exp \left(x_{j}^{\prime} \beta\right)}\right)^{\delta_{i}}
$$

이때, $R_{i}$ 는 시점 $t_{i}$ - 에서 생존해 있는 모든 사람들의 집합을 나타낸다. $\mathrm{BIC}$ 는 $\mathrm{AIC}$ 보다 계수에 수에 따른 벌점을 더 크게 하고 있으며, 일반적으로 $\mathrm{AIC}$ 보다 $\mathrm{BIC}$ 가 변수의 개수를 상대적으로 적게 선택하 는 경향이 있다 (Buckland 등, 1997).

하지만 변수선택에 있어 정보기준을 이용할 경우, 변수의 수가 늘어나면 변수들 간의 잠재적인 연관 성이나 교호작용이 늘어나 모형의 선택이 쉽지 않으며 (Agresti, 2007), 단계적 선택법과 마찬가지로 몇몇 특별한 모형의 경우를 제외하고는 모형 선택의 일치성과 같은 이론적 정당성을 부여하기 어렵다 (Konishi와 Kitagawa, 2008). 이러한 문제점을 해결하기 위하여 본 연구에서는 Shtatland 등 (2001)이 제안한 단계적 순열법(단계 1 , 단계2)을 통해 주요 인자를 선택하였다. 또한 선택된 주요 인자를 이용하 여, 추가적으로 2 차 교호작용까지 고려하는 모형(단계3)을 최종 모형으로 선택하기로 하겠다.

단계1. 자동화된 모형 선택방법인 단계별 선택 방법(stepwise selection method)의 변수 진입(forward selection)과 변수 제거(backward elimination)의 유의수준은 1 에 가깝게 정해준다. 그 결과로 가장 유의한 변수가 하나씩 순차적으로 모형에 진입하게 되는 설명변수의 단계별 순열(stepwise sequence)를 얻게 된다.

단계2. 단계적 순서를 통해 얻은 총 $p$ 개의 모형으로부터 $\mathrm{AIC}$ 및 $\mathrm{BIC}$ 값을 확인하여 이 값이 가장 적은 값을 가지는 모형에서 주효과 변수를 얻는다. 본 모형에서는 상대적으로 변수의 개수를 적게 선 택하는 정보기준인 $\mathrm{BIC}$ 를 바탕으로 모형을 선택하였다.

단계3. 단계 2 에서 선택된 모형의 주효과 변수들을 통해 고려할 수 있는 모든 2 차 교호작용 효과를 모형 에 추가한 후, 변수의 우도비테스트를 통하여 가장 유의하지 않은 변수를 하나씩 제거하는 후진 소거법 방법을 이용하여 최종 모형을 선택하였다.

\section{3. 실제자료로부터의 모형선택 결과}

이 절에서는 대졸자들의 첫 구직기간에 영향을 미치는 주요 요인에 대해 알아보기 위해 Cox의 비례위험 
Table 3.1. Stepwise sequence using Stepwise selection method.

\begin{tabular}{|c|c|}
\hline Stepwise Sequence & Select the variable \\
\hline Model 1 & Job searching experience \\
\hline Model 2 & Model $1+$ Householder \\
\hline Model 3 & Model $2+$ Specialist preparation \\
\hline Model 4 & Model $3+$ Type of school \\
\hline Model 5 & Model $4+$ English level \\
\hline Model 6 & Model $5+$ Living with parents \\
\hline Model 7 & Model 6 + Employment goals \\
\hline Model 8 & Model $7+$ Married \\
\hline Model 9 & Model $8+$ Job training experience \\
\hline Model 10 & Model $9+$ Major \\
\hline Model 11 & Model $10+$ Not a single major \\
\hline Model 12 & Model $11+$ Gender \\
\hline Model 13 & Model $12+$ Second language level \\
\hline Model 14 & Model 13 + Certification \\
\hline Model 15 & Model $14+$ Study abroad experience \\
\hline Model 16 & Model $15+$ Internship experience \\
\hline Model 17 & Model $16+$ GPA \\
\hline Model 18 & Model $17+$ Region of birth \\
\hline Model 19 & Model $18+$ Age \\
\hline Model 20 & Model $19+$ Family size \\
\hline Model 21 & Model $20+$ Admission/Transfer \\
\hline Model 22 & Model $21+$ Mother's education \\
\hline Model 23 & Model $22+$ Leave of Absence experience \\
\hline Model 24 & Model $23+$ College location \\
\hline Model 25 & Model $24+$ Father's education \\
\hline Model 26 & Model $25+$ Residence \\
\hline Model 27 & Model $26+$ Parents income during college entrance \\
\hline
\end{tabular}

모형을 이용하였다. 3.1절에서 언급했듯이 Table 2.2에 소개된 27 개의 변수로부터 생성되는 모든 가능 한 모형의 개수는 주효과만을 고려한다고 할지라도 $2^{27}$ 개인 $134,217,728$ 개이다. 이렇게 많은 모형을 고 려하는 것은 매우 비효율적이기 때문에 3.2절에서 소개한 모형 선택절차를 따르기로 한다. Table 3.1 은 단계적 선택법을 이용하여 27 개의 변수 중 첫 구직기간에 가장 유의한 영향을 미치는 변수를 얻은 단계 별 순열을 나타낸다.

단계적 선택법을 이용하여 얻은 27 개의 모형의 $\mathrm{AIC}$ 와 $\mathrm{BIC}$ 값은 Figure 3.1 과 같다. 앞서 언급한 것처 럼 $\mathrm{BIC}$ 는 $\mathrm{AIC}$ 보다 비교적 적은 변수의 모형이 더 효율적인 모형이라고 선택한다. 많은 변수로 자료를 설명하는 것보다 비교적 적은 변수로 자료를 설명하는 것이 효율적이기 때문에 본 연구에서는 모형 9 를 최종모형으로 선택하였다. 또한 본 연구에서는 추가적으로 각 변수들에 의한 교호작용을 살펴보기 위하 여 9 개의 주효과 변수로 만들 수 있는 36 개의 2 차 교호작용을 추가한 후, 후진소거법을 사용하여 얻은 최종모형은 Table 3.2 와 같다.

$\mathrm{Cox}$ 의 비례위험모형을 통해 인구학적 요인에서는 혼인상태와 본인의 가구주 여부, 부모님과의 동거 여 부가 선택되었으며, 학교생활 요인에서는 학교 유형과 영어성적, 구직 활동 요인에서는 취업 목표의 유 무와 일자리 탐색 경험 여부, 직업 훈련 및 교육 경험 여부, 전문시험 준비 경험 여부가 선택되었다. 또 한, 추가로 주효과들간의 교호작용이 선택되었다. Table 3.2 에서의 $x_{i}$ 의 수준이 $K$ 개일 때, $K$ 의 수준을 


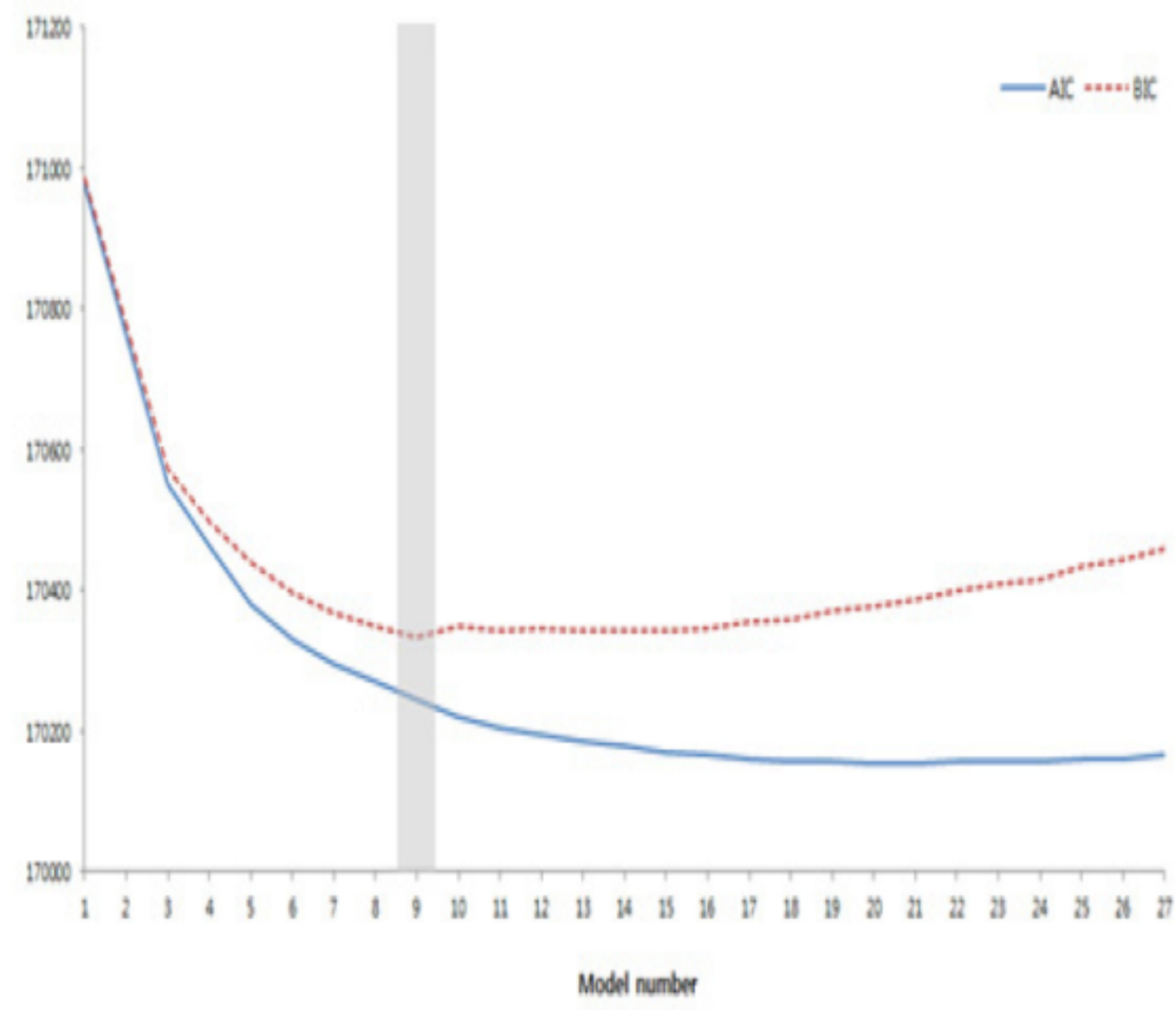

Figure 3.1. AIC and BIC for stepwise sequence

기준으로 한 $e^{\hat{\beta}_{i}}$ 의 의미는 다음과 같이 해당 변수의 상대적 위험도를 나타낸다.

$$
\frac{h\left(t \mid x_{1}, \ldots, x_{i-1}, x_{i}=k, x_{i+1}, \ldots, x_{p}\right)}{h\left(t \mid x_{1}, \ldots, x_{i-1}, x_{i}=K, x_{i+1}, \ldots, x_{p}\right)}, \quad(\text { 단, } k=1, \ldots, K-1) .
$$

구체적으로 살펴보면 인구학적 요인에서는 가족의 부양의무가 있는 대졸자가 취업할 가능성이 더 높았 는데, 기혼의 대졸자는 미혼의 대졸자보다 1.63 배, 본인이 가구주인 대졸자는 그렇지 않은 대졸자보다 2.41 배 높은 것을 알 수 있었다. 다음으로 부모님과 동거하는 대졸자가 또한 그렇지 않은 대졸자보다 취 업할 가능성이 높은 것을 알 수 있었는데, 이는 다른 독립변수를 제외하고 부모님과의 동거 여부 변수만 을 사용했던 Table 2.3 과는 반대의 결과이다. 이는 교호작용의 영향이며, 즉 부모님과의 동거여부와 관 련된 교호작용항의 계수를 살펴보면 모두 1 보다 작기 때문이다.

다음으로 학교생활 변수 중 학교유형에서는 4 년제 대졸자보다 전문대 대졸자가 취업할 가능성이 1.38 배 더 높고, 교육대 대졸자는 2.24 배 더 높다고 나타났다. 즉 교육대 대졸자들이 취업할 가능성이 가장 높 고 다음으로 전문대, 4 년제 대졸자 순으로 나타났다. 또한, 영어성적 문항에 응답하지 않은 대졸자들이 대체로 영어성적 질문에 응답한 대졸자보다 취업할 가능성이 높게 나타났지만, 이는 앞서 언급한 취업한 
Table 3.2. Cox's proportional hazard model estimation results.

\begin{tabular}{|c|c|c|c|}
\hline Varible (Level) & $e^{\beta}$ & $95 \% \mathrm{CI}$ & $p$-value \\
\hline Married (Yes/No) & 1.63 & $(1.32,2.01)$ & $<.0001$ \\
\hline Householder (Householder/Others) & 2.41 & $(2.10,2.78)$ & $<.0001$ \\
\hline Living with parents (Yes/No) & 1.92 & $(1.68,2.19)$ & $<.0001$ \\
\hline Type of school (College/University) & 1.38 & $(1.26,1.52)$ & $<.0001$ \\
\hline Type of school (University of education/University) & 2.24 & $(1.86,2.70)$ & $<.0001$ \\
\hline English level (Low/No response) & 0.76 & $(0.48,1.19)$ & 0.2249 \\
\hline English level (Middle/No response) & 0.67 & $(0.60,0.74)$ & $<.0001$ \\
\hline English level (High/No response) & 0.61 & $(0.54,0.70)$ & $<.0001$ \\
\hline Employment goals (Yes/No) & 1.25 & $(1.11,1.41)$ & 0.0002 \\
\hline Job searching experience (Yes/No) & 3.43 & $(2.84,4.13)$ & $<.0001$ \\
\hline Job training experience (Yes/No) & 1.90 & $(1.55,2.34)$ & $<.0001$ \\
\hline Specialist preparation (No/Yes) & 1.58 & $(1.39,1.80)$ & $<.0001$ \\
\hline Job searching experience(Yes/No)*Householder(Householder/Others) & 0.60 & $(0.51,0.70)$ & $<.0001$ \\
\hline Job searching experience(Yes/No)*Specialist preparation(No/Yes) & 0.87 & $(0.78,0.97)$ & 0.0129 \\
\hline Job searching experience(Yes/No)*Type of school(College/Univ.) & 0.75 & $(0.67,0.83)$ & $<.0001$ \\
\hline Job searching experience(Yes/No)*Type of school(Univ. of Edu./Univ.) & 0.60 & $(0.43,0.82)$ & 0.0015 \\
\hline Job searching experience(Yes/No)*English level(Low/No response) & 1.23 & $(0.73,2.05)$ & 0.4358 \\
\hline Job searching experience(Yes/No)*English level(Middle/No response) & 1.15 & $(1.02,1.30)$ & 0.0178 \\
\hline Job searching experience(Yes/No)*English level(High/No response) & 1.38 & $(1.20,1.58)$ & $<.0001$ \\
\hline Job searching experience(Yes/No)*Living with parents(Yes/No) & 0.62 & $(0.53,0.72)$ & $<.0001$ \\
\hline Job searching experience(Yes/No)*Employment goals(Yes/No) & 0.75 & $(0.69,0.83)$ & $<.0001$ \\
\hline Job searching experience(Yes/No)*Job training experience(Yes/No) & 0.70 & $(0.63,0.78)$ & $<.0001$ \\
\hline English level(Low/No response)*Married(Yes/No) & 0.54 & $(0.16,1.87)$ & 0.3315 \\
\hline English level(Middle/No response) $*$ Married(Yes/No) & 1.07 & $(0.80,1.44)$ & 0.6544 \\
\hline English level(High/No response) $*$ Married(Yes/No) & 1.55 & $(1.19,2.02)$ & 0.0011 \\
\hline English level(Low/No response)*Job training experience(Yes/No) & 0.84 & $(0.50,1.42)$ & 0.5204 \\
\hline English level(Middle/No response) $*$ Job training experience(Yes/No) & 1.15 & $(1.02,1.31)$ & 0.0245 \\
\hline English level(High/No response) $*$ Job training experience(Yes/No) & 1.29 & $(1.13,1.47)$ & 0.0002 \\
\hline Householder(Householder/Others)*English level(Low/No response) & 1.07 & $(0.63,1.81)$ & 0.7977 \\
\hline Householder(Householder/Others)*English level(Middle/No response) & 1.15 & $(1.03,1.29)$ & 0.0136 \\
\hline Householder(Householder/Others)*English level(High/No response) & 1.13 & $(1.00,1.27)$ & 0.0424 \\
\hline Householder(Householder/Others)*Living with parents(Yes/No) & 0.67 & $(0.50,0.90)$ & 0.0069 \\
\hline Householder(Householder/Others)*Job training experience(Yes/No) & 0.81 & $(0.68,0.97)$ & 0.0225 \\
\hline Type of school(College/Univ.)*Married(Yes/No) & 0.70 & $(0.53,0.93)$ & 0.0135 \\
\hline Type of school(Univ. of Edu./Univ.)*Married(Yes/No) & 1.51 & $(0.72,3.17)$ & 0.2732 \\
\hline Type of school(College/Univ.)*Job training experience(Yes/No) & 0.95 & $(0.84,1.07)$ & 0.4237 \\
\hline Type of school(Univ. of Edu./Univ.)*Job training experience(Yes/No) & 0.65 & $(0.49,0.85)$ & 0.0018 \\
\hline Specialist preparation(No/Yes)*Employment goals(Yes/No) & 1.12 & $(1.00,1.26)$ & 0.0422 \\
\hline Specialist preparation(No/Yes)*Married(Yes/No) & 0.74 & $(0.59,0.93)$ & 0.0098 \\
\hline Specialist preparation(No/Yes)*Job training experience(Yes/No) & 0.87 & $(0.78,0.98)$ & 0.0262 \\
\hline Living with parents(Yes/No)*Job training experience(Yes/No) & 0.80 & $(0.67,0.95)$ & 0.0099 \\
\hline
\end{tabular}

기업의 규모 등이 영향을 미친 것으로 보인다. 반면에 영어성적에 응답한 학생 중에서는 성적이 높을수 록 취업할 가능성이 높게 나타났다.

다음으로 구직 활동 변수에서는 취업을 위해 준비를 해왔던 대졸자들이 그렇지 않은 대졸자에 비해 취업 
할 가능성이 높게 나타났다. 먼저 취업 목표가 있는 대졸자가 목표가 없는 대졸자에 비해 취업할 가능성 이 1.25 배 높았으며, 일자리 탐색 경험이 있는 대졸자들은 경험이 없는 대졸자에 비해 3.43 배 정도 취업 할 가능성이 높았고, 직업 훈련 및 교육 경험이 있는 대졸자가 경험이 없는 대졸자에 비해 취업할 가능 성이 1.9 배 높았다. 반면에 전문시험 준비 경험이 없는 학생이 경험이 있는 학생보다 1.58 배 정도 취업 할 가능성이 높은 것을 알 수 있었는데, 이는 전문시험의 준비 기간이 취업 기간에 영향을 준 것을 볼 수 있었다.

마지막으로 교호작용을 살펴보면 대체로 일자리 탐색 경험과 관련된 교호작용이 가장 많이 발생하였으 며, 다음으로는 직업 훈련 및 교육 경험, 영어성적과 본인의 가구주 여부, 그리고 전문시험 준비 경험 등 의 교호작용이 발생하였다.

\section{4. 결론 및 향후과제}

본 연구에서는 한국고용정보원의 패널 조사인 ‘대졸자 직업이동 경로조사' 중 2008 GOMS1 자료를 가 지고 대학 졸업 후 첫 구직기간에 대해 살펴보았다. 현재 통계청과 한국고용정보원, 그리고 그 외의 여 러 조사기관에서는 첫 구직기간과 취업률에 관하여 발표하고 있다. 하지만 조사기관에 따라 첫 구직기 간에 대한 산정기준이 서로 다른 것을 알 수 있었고, 이는 실제 우리나라 청년들이 느끼는 첫 구직기간 과 취업률과도 상당한 차이가 있었다. 때문에 본 연구에서는 좀 더 현실적인 첫 구직기간을 산정하기 위 해서 새로운 산정기준을 제시하고, 첫 구직기간에 영향을 미치는 개인의 요인들을 자세하게 살펴보았다.

먼저 본 연구에서의 첫 구직기간은 실제 졸업 후 첫 일자리를 구하는 데까지 걸리는 기간이 아닌 다수 기업의 공채 시기에서부터 첫 일자리를 구하는 데까지 걸리는 기간(졸업 전 4 개월)으로 산정하였다. 그 결과, 졸업 후 4 개월 내 취업하는 대졸자가 $31 \%$ 라는 것을 알 수 있었는데, 이것은 졸업과 동시에 취업 상태에 있는 대졸자가 $31 \%$ 라는 것을 의미한다. 또한, 졸업 후 2 개월이 지나야 대졸자의 $51 \%$ 가 첫 구직 에 성공한다는 것을 알 수 있었다.

다음으로 인구학적인 요인들과 학교생활과 관련된 요인들 그리고 구직활동과 관련된 요인들이 첫 구직 기간에 구체적으로 어떠한 영향을 미치는지를 살펴보았다.

첫째, 인구학적 요인 중에서는 혼인상태와 본인의 가구주 여부, 부모님과의 동거 여부가 첫 구직기간과 유의한 관련이 있었다. 주로 가족 간의 관계가 첫 구직기간과 유의한 관련이 있으며, 특히 가족 부양의 무를 가지고 있는 기혼 및 가구주, 부모님과 동거를 하는 대졸자가 다른 대졸자에 비하여 취업을 할 가 능성이 높은 것을 알 수 있었다. 이는 Jo (2009)의 결과인 기혼일수록, 가구주일수록 첫 구직기간이 짧 았다는 결과와 일치한다. 둘째, 학교생활 관련 요인 또한 첫 구직기간에 유의한 영향을 주는 것으로 나 타났다. 먼저 학교의 유형별 결과에 따르면 교육대의 대졸자가 대졸 후 첫 일자리를 가장 빨리 구하는 것으로 나타났으며, 다음으로는 전문대, 4 년제 대졸자 순인 것을 알 수 있었다. 또한, 영어성적이 첫 구 직기간에 영향을 미치는 것을 알 수 있었다. 비록 영어성적 질문에 응답하지 않은 대졸자들이 많아 결 과에 타당성을 확보할 수는 없었지만, 영어성적 질문에 응답한 졸업자 중에서는 영어성적이 높을수록 첫 구직기간이 짧은 것을 알 수 있었다. 셋째, 구직활동과 관련된 변수에서는 대체로 대학 재학 중 취업에 도움을 주는 활동을 한 대졸자일수록 첫 구직기간이 짧은 것을 알 수 있었다. 이는 취업에 대한 적극적 인 자세가 첫 구직기간에 영향을 준다는 것을 의미하는데, 취업을 위한 직업교육-훈련은 취업을 용이하 게 해 준다고 발표한 Park (2005)에서의 결과와 일치한다. 구체적으로 취업 관련 경험 중 일자리 탐색 경험과 직업 훈련 및 교육 경험, 취업 목표의 유무가 첫 구직기간에 영향을 준다고 나타났다. 반면에 전 문시험 준비 경험이 있으면 취업이 늦는 것을 알 수 있었는데, 전문시험의 범주에는 공무원, 교원임용 시험, 회계사, 법무사 등이 있는 것으로 보아 기업 취직의 관심이 다른 대졸자에 비해 더 적기 때문이라 
Table 4.1. Combination of top five characteristics of probability to be employed.

\begin{tabular}{|c|c|c|c|c|c|c|c|c|c|c|}
\hline Case & Married & $\begin{array}{l}\text { House } \\
\text { holder }\end{array}$ & $\begin{array}{c}\text { Living } \\
\text { with } \\
\text { parents }\end{array}$ & $\begin{array}{c}\text { Type } \\
\text { of } \\
\text { School }\end{array}$ & $\begin{array}{c}\text { English } \\
\text { level }\end{array}$ & $\begin{array}{l}\text { Employ- } \\
\text { ment goal }\end{array}$ & $\begin{array}{c}\text { Job } \\
\text { searching } \\
\text { experience }\end{array}$ & $\begin{array}{c}\text { Job } \\
\text { training } \\
\text { experience }\end{array}$ & $\begin{array}{c}\text { Specialist } \\
\text { preparation }\end{array}$ & $\frac{h_{c}(t)}{h_{0}(t)}$ \\
\hline 0 & $\mathrm{x}$ & $\mathrm{x}$ & $\mathrm{x}$ & Univ. & $\begin{array}{c}\text { No } \\
\text { response }\end{array}$ & $\mathrm{x}$ & $\mathrm{x}$ & $\mathrm{x}$ & $\mathrm{x}$ & 1.0 \\
\hline 1 & o & o & o & $\begin{array}{l}\text { Univ. } \\
\text { of Edu. }\end{array}$ & High & o & $\mathrm{x}$ & $\mathrm{x}$ & o & 30.5 \\
\hline 2 & o & o & o & $\begin{array}{l}\text { Univ. } \\
\text { of Edu. }\end{array}$ & $\begin{array}{c}\text { No } \\
\text { response }\end{array}$ & o & $\mathrm{x}$ & $\mathrm{x}$ & o & 28.4 \\
\hline 3 & o & o & o & $\begin{array}{l}\text { Univ. } \\
\text { of Edu. }\end{array}$ & High & o & $\mathrm{x}$ & o & o & 27.2 \\
\hline 4 & o & o & $\mathrm{x}$ & $\begin{array}{l}\text { Univ. } \\
\text { of Edu. }\end{array}$ & High & o & $\mathrm{x}$ & o & o & 26.6 \\
\hline 5 & o & o & $\mathrm{x}$ & $\begin{array}{l}\text { Univ. } \\
\text { of Edu. }\end{array}$ & High & o & o & $\mathrm{x}$ & o & 26.1 \\
\hline
\end{tabular}

Table 4.2. Combination of top five characteristics of probability to be employed within 4 year course university graduates.

\begin{tabular}{|c|c|c|c|c|c|c|c|c|c|c|}
\hline Case & Married & $\begin{array}{l}\text { House } \\
\text { holder }\end{array}$ & $\begin{array}{l}\text { Living } \\
\text { with } \\
\text { parents }\end{array}$ & $\begin{array}{c}\text { Type } \\
\text { of } \\
\text { School }\end{array}$ & $\begin{array}{c}\text { English } \\
\text { level }\end{array}$ & $\begin{array}{l}\text { Employ- } \\
\text { ment goal }\end{array}$ & $\begin{array}{c}\text { Job } \\
\text { searching } \\
\text { experience }\end{array}$ & $\begin{array}{c}\text { Job } \\
\text { training } \\
\text { experience }\end{array}$ & $\begin{array}{c}\text { Specialist } \\
\text { preparation }\end{array}$ & $\frac{h_{c}(t)}{h_{0}(t)}$ \\
\hline 0 & $\mathrm{x}$ & $\mathrm{x}$ & $\mathrm{x}$ & Univ. & $\begin{array}{c}\text { No } \\
\text { response }\end{array}$ & $\mathrm{x}$ & $\mathrm{x}$ & $\mathrm{x}$ & $\mathrm{x}$ & 1.0 \\
\hline 52 & o & o & $\mathrm{x}$ & Univ. & High & $\mathrm{x}$ & o & o & o & 16.6 \\
\hline 62 & o & $\mathrm{o}$ & $\mathrm{x}$ & Univ. & High & o & o & o & o & 15.8 \\
\hline 64 & o & $\mathrm{O}$ & $\mathrm{x}$ & Univ. & High & $\mathrm{O}$ & o & o & $\mathrm{x}$ & 15.7 \\
\hline 73 & o & o & $\mathrm{x}$ & Univ. & High & $\mathrm{x}$ & o & o & o & 14.8 \\
\hline 106 & o & o & $\mathrm{x}$ & Univ. & High & o & o & $\mathrm{x}$ & o & 12.9 \\
\hline
\end{tabular}

고 할 수 있겠다.

다음으로 주효과의 교호작용이 첫 구직기간에 유의한 영향을 미치는 것을 알 수 있었는데, 이러한 주효 과와 교호작용의 효과를 고려하여 대졸자들의 모든 가능한 특성의 수준조합에 대하여 취업가능성을 살 펴보았다. Table 4.1은 이러한 모든 가능한 수준조합 중 취업가능성이 비교적 높은 대졸자의 상위 5 개 사례를 나타낸 것이다.

Table 4.1에서 가장 취업이 잘 될 것으로 추정된 대졸자의 속성은 기혼자이면서 본인이 가구주이고, 부 모님과 함께 동거하면서 교육대를 졸업하였으며, 영어성적은 상위권에 속하고 취업에 대한 목표가 뚜렷 하며 일자리 탐색 경험과 직업 훈련 및 교육 경험이 없고 전문시험 준비경험이 있는 대졸자(사례 1 에 해 당)라고 나타났다. 이는 기준이 되는 대졸자(사례 0 에 해당)보다 취업할 확률이 30 배 이상 높은 것을 알 수 있다. Table 4.1 을 자세히 살펴보면, 상위 5 개의 사례의 경우 모두 기혼이며, 본인이 가구주이고 교 육대 졸업자인 것을 알 수 있다. 또한, 대체적으로 취업목표와 전문시험 준비 경험이 있는 대졸자가 비 교적 취업할 가능성이 높다고 나타난 것을 알 수 있다. 그러나 표 10 에서 알 수 있듯이 상위 5 개의 사 례에서 모두 교육대 대졸자가 취업할 가능성이 높다고 나타났지만, 이는 교육대 대졸자의 취업의 성격과 4 년제 또는 전문대 대졸자과는 다르다고 판단하여 Table 4.2 와 Table 4.3 과 같이 4 년제와 전문대 대졸 
Table 4.3. Combination of top five characteristics of probability to be employed within college graduates.

\begin{tabular}{ccccccccccc}
\hline Case & Married & $\begin{array}{c}\text { House } \\
\text { holder }\end{array}$ & $\begin{array}{c}\text { Living } \\
\text { with } \\
\text { parents }\end{array}$ & $\begin{array}{c}\text { Type } \\
\text { of } \\
\text { School }\end{array}$ & $\begin{array}{c}\text { English } \\
\text { level }\end{array}$ & $\begin{array}{c}\text { Employ- } \\
\text { ment goal }\end{array}$ & $\begin{array}{c}\text { Job } \\
\text { searching } \\
\text { experience }\end{array}$ & $\begin{array}{c}\text { Job } \\
\text { training } \\
\text { experience }\end{array}$ & $\begin{array}{c}\text { Specialist } \\
\text { preparation }\end{array}$ & $\begin{array}{c}h_{c}(t) \\
h_{0}(t)\end{array}$ \\
\hline 0 & $\mathrm{x}$ & $\mathrm{x}$ & $\mathrm{x}$ & Univ. & $\begin{array}{c}\text { No } \\
\text { response }\end{array}$ & $\mathrm{x}$ & $\mathrm{x}$ & $\mathrm{x}$ & $\mathrm{x}$ & $\mathrm{o}$ \\
\hline 139 & $\mathrm{o}$ & $\mathrm{o}$ & $\mathrm{o}$ & College & High & $\mathrm{o}$ & $\mathrm{x}$ & $\mathrm{o}$ & 1.0 \\
\hline 140 & $\mathrm{o}$ & $\mathrm{o}$ & $\mathrm{x}$ & College & High & $\mathrm{x}$ & $\mathrm{o}$ & $\mathrm{o}$ & $\mathrm{x}$ & 11.4 \\
\hline 148 & $\mathrm{o}$ & $\mathrm{o}$ & $\mathrm{x}$ & College & High & $\mathrm{o}$ & $\mathrm{x}$ & $\mathrm{o}$ & $\mathrm{o}$ & 11.2 \\
\hline 153 & $\mathrm{o}$ & $\mathrm{o}$ & $\mathrm{x}$ & College & High & $\mathrm{o}$ & $\mathrm{o}$ & $\mathrm{o}$ & $\mathrm{o}$ & 10.9 \\
\hline 155 & $\mathrm{o}$ & $\mathrm{o}$ & $\mathrm{x}$ & College & High & $\mathrm{o}$ & $\mathrm{o}$ & $\mathrm{x}$ & $\mathrm{x}$ & 10.8 \\
\hline
\end{tabular}

자의 상위 5 개의 특성조합을 추가적으로 살펴보았다.

위와 같은 본 연구의 분석결과를 살펴보면 대졸자 중 심리적 부담감을 갖고 구직활동에 열심인 대졸자가 첫 구직에 성공할 가능성이 높다는 것을 알 수 있었다. 대체적으로 가족의 부양의무를 가지고 있는 대졸 자의 경우가 그렇지 않은 대졸자보다 구직할 가능성이 높았으며, 구직활동에 노력의 행위를 보인 대졸자 가 그 밖의 대졸자 보다 구직할 가능성이 높게 나타났다. 또한, 학교생활 중 영어성적을 높인다거나 취 업목표를 갖고 꾸준히 일자리 탐색이나 직업 훈련 및 교육을 받는 등 구직활동에 적극적인 경우가 취업 할 가능성이 높다는 것을 알 수 있었다.

\section{Acknowledgements}

논문에서 사용한 자료를 소개해주시고 분석에 조언을 해주신 주신 고용노동부 정향숙 사무관님과 세심 한 심사를 해주신 심사위원분들께 진심으로 감사드립니다.

\section{References}

Achen, C. H. (1982). Interpreting and Using Regression, Sage Publications, 76-89.

Agresti, A. (2007). An Introduction to Categorical Data Analysis, John Wiley \& Sons, New York.

Akaike, H. (1973). Information Theory and an Extension of the Maximum Likelihood Principle, Second International Symposium on Information Theory, 267-281, Akademiai Kiado, Budapest.

Akaike, H. (1974). A new look at the statistical model identification, IEEE Transactions on Automatic Control, 19, 716-723.

Buckland, S. T., Burnham, K. P. and Augustin, N. H. (1997). Model Selection: An integral part of inference, Biometric, 53, 603-618.

Cox, D. R. (1972). Regression models and life tables(with discussion), Journal of the Royal Statistical Society, B, 34, 187-220.

Cox, D. R. (1975). Partial likelihood, Biometrika, 62, 269-276.

Frisch, R. (1934). Statistical Confluence Analysis by Means of Complete Regression Systems, Institute of Economics, Oslo University Publish, 5.

Jo, M. S. (2009). An Empirical Study on the School to Work Transition of College Graduates: Determinants of Success Rate, Duration, and Wage Differential, Degree of Master, Inha University.

Kaplan, E. L. and Meier, P. (1958). Nonparametric estimation from incomplete observations, Journal of the American Statistical Association, 53, 457-481.

Konishi, S. and Kitagawa, G. (2008). Information Criteria and Statistical Modelling, Springer-Verlag, New York. 
Park, S. J. (2005). The status of youth unemployment and its causal analysis, Korea Economic Research Institute Policy Report.

Schwarz, G. (1978). Estimating the dimension of a model, Annals of Statistics, 6, 290-301.

Shtatland, E. S., Cain, E. M. and Barton, M. B. (2001). The perils of stepwise logistic regression and how to escape them using information criteria and the Output Delivery System, SUGI'26 Proceedings, 222-226, Cary, NC: SAS Institute Inc.

Shtatland, E. S., Kleinman, K. and Cain, E. M. (2005). Model building in proc phreg with automatic variable selection and information criteria, SUGI'30 Proceedings, 206-30, Cary, NC: SAS Institute Inc.

Volinsky, C. T. and Raftery, A. E. (2000). Bayesian information criterion for censored survival models, Biometrics, 56, 256-262. 